\title{
Microsatellite and EGFR, HER2 and K-RAS Analyses in Sclerosing Hemangioma of the Lung
}

\author{
Giuliana Sartori, PhD, * Stefania Bettelli, BSc, ${ }^{*}$ Laura Schirosi, PhD, * Nazzarena Bigiani, PhD,* \\ Antonio Maiorana, MD, * Alberto Cavazza, MD, $\dagger$ and Giulio Rossi, MD*
}

\begin{abstract}
Sclerosing hemangioma $(\mathrm{SH})$ is an uncommon pulmonary tumor thought to derive from primitive respiratory epithelium consisting of 2 cell populations (cuboidal surface and polygonal stromal cells) and sharing some clinical characteristics (frequent occurrence in nonsmoking women of Asian ethnicity) with bronchioloalveolar carcinoma with which it has been suggested a possible common origin. We investigated 11 cases of SH by immunohistochemistry, fluorescence in situ hybridization, and polymerase chain reaction-based microsatellite and mutational analyses with particular emphasis on possible alterations of microsatellite loci located at tumor suppressor genes (FHIT, $p 16, R b$, and $p 53)$ involved in lung adenocarcinoma genesis and EGFR, HER2, and $K-R A S$ genes. Although EGFR expression was observed in all tested cases, none showed HER 2 immunostaining. Fluorescence in situ hybridization and mutational analysis of EGFR and HER2 and also $K$-RAS sequencing did not reveal molecular alterations, whereas allelic losses at p16 and $R b$ loci (4 and 2 out of 9 tested cases, respectively) with an identical microsatellite allelic loss pattern in both cuboidal and polygonal cells were observed. The finding of microsatellite alterations in chromosomal regions related to genes deeply involved in early stage lung adenocarcinoma could suggest a possible link between $\mathrm{SH}$ and bronchioloalveolar carcinoma, but tumor pathway promoted by EGFR, HER2, and $K-R A S$ does not represent a common molecular mechanism of tumorigenesis. Microsatellite alterations identified in cuboidal and polygonal cells further confirm the clonal and neoplastic nature of both components of $\mathrm{SH}$.
\end{abstract}

Key Words: lung, sclerosing hemangioma, EGFR, K-RAS, $\mathrm{LOH}$

(Am J Surg Pathol 2007;31:1512-1520)

$S_{c}^{c}$ clerosing hemangioma ( $\mathrm{SH})$, also know as pneumocytoma, is an uncommon benign neoplasm of the lung first described by Liebow and Hubbell ${ }^{16}$ in 1956 and included in the "miscellaneous tumor" category in the

From the *Section of Pathologic Anatomy, Azienda Policlinico, Modena; and †Operative Unit of Pathology, Azienda Hospital Santa Maria Nuova, Reggio Emilia, Italy.

Reprints: Dr Giulio Rossi, MD, Sezione di Anatomia Patologica, Azienda Policlinico, Via del Pozzo, 71-41100-Modena, Italy (e-mail: rossi.giulio@policlinico.mo.it).

Copyright (C) 2007 by Lippincott Williams \& Wilkins most recent World Health Organization (WHO) classification of lung tumors. ${ }^{33}$

SH has 4 basic histologic patterns (solid, hemorrhagic, papillary, and fibrotic) often mixed with each other, and 2 cell populations consisting of surface cuboidal cells lining the papillae and polygonal stromal cells growing in the interstitium. ${ }^{33}$ The tumor has been the subject of several controversies about its histogenesis and, although it is now accepted that the polygonal cells are neoplastic and take origin from primitive respiratory epithelium, some controversies remain about the nature of the surface cuboidal cells (entrapped alveoli? a complete differentiation of the polygonal ones?) and the relationship between the 2 cell types. ${ }^{6,10,14,27,34,37,39,41}$ To date, no systemic metastases have been reported for this tumor, while it can show cellular atypia, foci of vascular invasion, and metastatic deposits into the regional lymph nodes. ${ }^{20,32,38}$ However, none of these features seems to affect the good prognosis of patients with $\mathrm{SH} .{ }^{20}$

It is surprising to note that both $\mathrm{SH}$ and nonmucinous type bronchioloalveolar carcinoma (nm-BAC) share several clinical characteristics, given that both neoplasms most commonly occur in nonsmoking, middle-aged women of East Asia ethnicity. ${ }^{33}$ Several works recently demonstrated that patients with nm-BAC or pulmonary adenocarcinoma with prominent BAC features are also frequently characterized by somatic and mutually exclusive mutations involving EGFR or HER2 genes, particularly when patients are nonsmoker, women, and native from Asia. 3,4,7,11,17-19,23-25,29-31,40 Of note, EGFR mutational events seem to be quite specific of lung adenocarcinoma with BAC features. ${ }^{17,18}$ In addition, a recent work by Dacic et $\mathrm{al}^{9}$ suggested a common origin for $\mathrm{SH}$ and nm-BAC on the basis of the finding of similar patterns of allelic loss using a panel of 7 polymorphic microsatellite markers located on chromosomal regions encoding for tumor suppressor genes involved in pulmonary adenocarcinoma tumorigenesis.

We report here the results of an immunohistochemical, fluorescence in situ hybridization (FISH), and polymerase chain reaction (PCR)-based molecular study by means of loss of heterozygosity $(\mathrm{LOH})$ analysis using a panel of markers identifying tumor suppressor genes thought to be key molecules in the neoplastic sequential events of lung adenocarcinomagenesis (FHIT, p16, Rb, p53) $)^{1,2,8,12,28,35,36}$ and also direct sequencing of EGFR (exons 18-21), HER2 (exons 19 and 20), and $K$-RAS 
(exon 2) genes in a series of $11 \mathrm{SH}$. This work was aimed at further investigating the molecular mechanisms underlying $\mathrm{SH}$ tumorigenesis also in view of the relationship between SH and nm-BAC. In 8 cases, a separate analysis of the dual cell component of SH was performed to better clarify their molecular profile.

\section{MATERIALS AND METHODS}

The files of the Sections of Pathologic Anatomy of the University of Modena and Reggio Emilia and of the St Maria Nuova Hospital of Reggio Emilia were searched for surgical cases of pulmonary SH. Overall, 11 cases (7 from routine practice and 4 from consultation files) were collected from January 1990 to December 2005 and all the available slides were then reviewed at a multiheaded microscope by 2 pathologists (G.R., A.C.) according to the criteria set by the new WHO lung tumors classification. ${ }^{33}$ One case has been previously reported. ${ }^{5}$ All these cases consisted of a surgical specimen (6 wedge resections and 5 pulmonary lobectomies) that was routinely fixed in $10 \%$ buffered-formalin. After gross examination, the sampled tissues were embedded in paraffin blocks. A mean of 2.5 (range, 2 to 4) hematoxylin-eosin-stained slides per tumor were available. Clinical data were collected from pathologic reports, clinical charts, referring physicians, or directly from the patient's families.

\section{Immunohistochemical Analysis}

In each case, $2-\mu \mathrm{m}$-thick sections were obtained from a representative block. Sections were air-dried overnight at $37^{\circ} \mathrm{C}$, then deparaffinized in xylene and rehydrated through a decreasing concentration of alcohol to water. Endogenous peroxidase activity was blocked by immersion for 10 minutes with $3 \%$ hydrogen peroxide $\left(\mathrm{H}_{2} \mathrm{O}_{2}\right)$ in methanol. Incubation with primary antibodies was accomplished with a modified streptavidin-biotinperoxidase technique using an automated immunostainer (Benchmark, Ventana, Tucson, AZ); 3'-3 diaminobenzidine was used as the chromogene and Harris's hematoxylin as the counterstain. The antibodies used in the study and their technical characteristics are the following: TTF1 (clone 8G7G3/3, Dako; 1:100 dilution; antigen retrieval by microwave), EMA (clone E29, Dako; 1:100 dilution; no antigen retrieval), cytokeratin (clone MNF116, Dako; 1:1500 dilution; protease pretreatment), EGFR (clone 31G7, Ventana; pre-diluted; protease pretreatment), HER2/neu (clone CB11, Novocastra, Newcastle upon Tyne, UK; 1: 150 dilution; microwave). Negative and positive controls were included in each batch.

For each antibody, the percentage of positive cells and the intensity of staining (0: negative; $1+$ : weak; $2+$ : moderate; $3+$ : strong) were recorded. A tumor was considered positive when at least $10 \%$ of the neoplastic cells reacted with an intensity of $2+$ or greater on the relevant subcellular localization (nuclear for TTF-1; cytoplasmic for cytokeratin; cytoplasmic and/or membranous for EMA, EGFR, and HER2).

\section{Microsatellite Analysis}

Five- $\mu \mathrm{m}$-thick, hematoxylin-eosin-stained sections from a representative paraffin-embedded block were applied on noncover-slipped slides for microdissection and DNA extraction. Briefly, microdissection was performed under direct observation with an inverted microscope using a sterile needle. Lymphocytes from a reactive sampled lymph node were similarly microdissected and served as sources of constitutional DNA (control). Each microdissected sample from the different components and from lymphocytes was directly transferred to an eppendorf tube containing digestion buffer $[2 \mathrm{mg} / \mathrm{mL}$ proteinase $\mathrm{K}$ in $50 \mathrm{mM}$ Tris (pH8.5), $1 \mathrm{mM}$ EDTA, $0.5 \%$ Tween 20$]$. The tubes were then incubated overnight at $37^{\circ} \mathrm{C}$, and followed by 10 minutes of incubation at $95^{\circ} \mathrm{C}$ to eliminate any remaining proteinase $\mathrm{K}$ activity. PCR was performed in $10 \mu \mathrm{L}$ reaction mixture containing $25 \mathrm{pmol}$ each of primers, $1 \mu \mathrm{L}$ of extracted DNA from at least 100 cells, $200 \mu \mathrm{M}$ each of deoxynucleoside triphosphate, $1.5 \mathrm{mM}$ of magnesium chloride, $1 \mu \mathrm{L}$ of commercial PCR buffer (Applied Biosystem, Applera Italy, Monza, Italy) and 1.5 unit of AmpliTaq gold polymerase (Applied Biosystem). The amplified PCR products were then run on $4 \%$ denaturing polyacrylamide gel for the ABI-Prism 310 automatic sequencer (Applied Biosystem) with a labeled marker (TAMRA 500) as an internal size standard. Seven primer sequences (MWG-Biotech, Florence, Italy) flanking 7 microsatellite repeat polymorphisms located at 4 chromosomal regions were used, as follows: D3S1300 and D3S1312 (FHIT), D9S171 and D9S162 (p16), D13S153 and D13S176 (Rb), and TP53 (D17). The data were analyzed with the Gene Mapper 3.7 software (Applied Biosystem). Microsatellite analysis was performed by comparing the positions of the bands corresponding to the tumor and the normal DNA according to the manufacturer's manual. Briefly, peak height of each microsatellite locus for independent injections of each normal and each tumor sample was obtained. Length variation was determined when the electropherogram showed the presence of novel peaks, with an evident shift, in the tumor DNA, which was not present in normal DNA. LOH was also detected and was defined as the loss of a wild-type allele (peak) in tumor compared with normal DNA. The mathematic model of LOH determination used is the following: height of normal allele 2/height of normal allele one height of tumor allele 2/height of tumor allele 1 .

An $\mathrm{LOH}$ value $\leq 0.5$ indicated that the tumor sample showed significant loss of the longer allele whereas an $\mathrm{LOH}$ value $\geq 1.5$ indicated a significant loss of the shorter allele. Results were confirmed in all cases in duplicate experiments using independently extracted DNA samples.

\section{FISH Analysis}

FISH to detect $E G F R$ and HER2 gene copy number was performed using the Dual-color, Dual-fusion LSI EGFR Spectrum Orange/CEP7 Spectrum Green-labeled and Dual-color, Dual-fusion HER2 Spectrum Orange/ CEP17 Spectrum Green-labeled FISH probes obtained 
from Vysis (Vysis, Downers Grove, IL) on 3- $\mu$ m-thick sections obtained from a representative tumor block. The sections were incubated at $60^{\circ} \mathrm{C}$ overnight, deparaffined in xylene washes, and partially hydrated in $100 \%$ and $95 \%$ ethanol for 2 minutes. The sections were then incubated in $0.2 \mathrm{~N} \mathrm{HCl}$ at room temperature for 20 minutes, incubated with pretreatment solution at $80^{\circ} \mathrm{C}$ for 30 minutes, digested with protease I solution at $42^{\circ} \mathrm{C}$ for 15 minutes, rinsed in phosphate-buffered saline for 5 minutes and air-dried. The probe set was applied to the tumor on each slide and covered with a glass coverslip. The slides were incubated at $85^{\circ} \mathrm{C}$ for 3 minutes for codenaturation of chromosomal and probe DNA, and hybridated at $37^{\circ} \mathrm{C}$ for 16 hours using the Hybrite System. Posthybridization washes were performed in $2 \mathrm{X}$ $\mathrm{SSC} / 0.3 \% \mathrm{NP} 40$ for 2 minutes at $75^{\circ} \mathrm{C}$. After air-dried, the slides were mounted with DAPI/Antifade. EGFR/ $H E R 2$ gene copy number analysis was performed under an Axiophot Zeiss fluorescent microscope equipped with a specific workstation. At least 100 nonoverlapping interphase tumor nuclei per case were scored by 2 independent investigators (S.B., L.S.), counting the number of orange (EGFR/HER2) and green (chromosome 7 and 17 centromers) spots. Cases were classified as FISH-negative when there was a disomy for both $E G F R /$ HER 2 genes and chromosome 7/chromosome 17 (the ratio of $E G F R / \mathrm{Cr} 7$ or $H E R 2 / \mathrm{Cr} 17=1)$. Cases were recorded as FISH-positive when contained either more than 4 copies of the chromosomes 7 or 17 per cell or showed gene amplification ( $>2$ copies of the gene per chromosome).

\section{Mutational Analysis}

Five- $\mu$ m-thick sections obtained from a representative paraffin-embedded block were deparaffinized by xylene, and tumor DNA was extracted using an identical manual microdissection method as previously described. Microdissected tumor cells were subject to proteinase $\mathrm{K}$ treatment in a digestion buffer $[50 \mathrm{mM}$ Tris $(\mathrm{pH} 8.5)$, $1 \mathrm{mM}$ EDTA, $0.5 \%$ Tween 20] and then incubated overnight at $37^{\circ} \mathrm{C}$. PCR was performed in $20 \mu \mathrm{L}$ reactions containing $2.0 \mu \mathrm{L}$ DNA, $2 \mu \mathrm{L}$ of commercial PCR buffer (Applied Biosystem), 1.0 to $1.5 \mathrm{mM}$ of $\mathrm{MgCl}_{2}, 200 \mu \mathrm{M}$ of each dNTP, $20 \mathrm{pmol}$ of each primer, and 3 units of AmpliTaq gold polymerase (Applied Biosystem). PCR reaction was carried out on Uno II Thermoblock (Biometra, Gottingen, Germany). Initial denaturation at $94^{\circ} \mathrm{C}$ for 10 minutes was followed by 41 cycles, and a final extension step $\left(7\right.$ minutes at $\left.72^{\circ} \mathrm{C}\right)$. The cycles included denaturation at $95^{\circ} \mathrm{C}$ for 1 minute, annealing at $55^{\circ} \mathrm{C}$ to $58^{\circ} \mathrm{C}$ for 1 minute, and extension at $72^{\circ} \mathrm{C}$ for 2 minutes. The amplified DNA was electrophoresed on $2 \%$ agarose gel for 1 hour at $110 \mathrm{~V}$. The amplification products were then purified by using MinElute PCR purification Kit (Qiagen) as indicated by the manufacturer's instructions. PCR products were then sequenced in both directions with ABI Prism BigDye Terminator v1.1 Cycle Sequencing kit (Applied Biosystems), using the same primers as those employed for PCR. PCR products were finally purified by Centri-Sep Spin Columns (Applied Biosystem) and subsequently ran on the ABI Prism 310 automatic sequencer (Applied Biosystems). The data were analyzed with the Sequencing Analysis 5.2 Software (Applied Biosystem). The forward and reverse oligonucleotide primers used to amplify EGFR exons 18, 19, 20 and 21, $H E R 2$ exons 19 and 20 and $K-R A S$ exon 2 are listed in Table 1 .

\section{RESULTS}

As summarized in Table 2, the case series consisted of 10 women and 1 man, all whites, with a median age of 46.8 years. Eight patients were nonsmokers and 5 presented symptoms at diagnosis, while the tumor was incidentally found in 6 cases. All patients were alive and well (mean follow-up, $59.1 \mathrm{mo}$; range, 33 to $119 \mathrm{mo}$ ) including the only 1 with regional lymph node metastasis.

\begin{tabular}{|c|c|c|}
\hline Gene and Exons & $\begin{array}{c}\text { Fragment } \\
\text { Size } \\
\text { (bp) }\end{array}$ & $\begin{array}{c}\text { Annealing } \\
\text { Temperature }\left({ }^{\circ} \mathrm{C}\right) \\
\end{array}$ \\
\hline$K-R A S$ & \multirow{4}{*}{176} & \multirow{4}{*}{52} \\
\hline Exon 2 & & \\
\hline $\begin{array}{l}\text { Forward 5'-CAT GTT CTA ATA } \\
\text { TAG TCA CA-3' }\end{array}$ & & \\
\hline $\begin{array}{l}\text { Reverse } 5^{\prime} \text {-AAC AAG ATT TAC } \\
\text { CTC TAT TG-3' }\end{array}$ & & \\
\hline$E G F R$ & \multirow{4}{*}{381} & \multirow{4}{*}{65} \\
\hline Exon 18 & & \\
\hline $\begin{array}{c}\text { Forward 5'-CAA GTG CCG TGT } \\
\text { CCT GGC ACC CAA GC-3' }\end{array}$ & & \\
\hline Reverse 5'-CCA AAC ACT CAG & & \\
\hline $\begin{array}{l}\text { TGA AAC AAA GAG-3' } \\
\text { Exon } 19\end{array}$ & \multirow[t]{2}{*}{297} & \multirow[t]{2}{*}{57} \\
\hline $\begin{array}{l}\text { Forward 5'-GTG CAT CGC TGG } \\
\text { TAA CAT CC-3' }\end{array}$ & & \\
\hline $\begin{array}{l}\text { Reverse } 5^{\prime} \text {-TGT GGA GAT GAG } \\
\text { CAG GGT CT-3' }\end{array}$ & \multirow{3}{*}{372} & \multirow{3}{*}{56} \\
\hline Exon 20 & & \\
\hline $\begin{array}{l}\text { Forward 5'-ATC GCA TTC ATG } \\
\text { CGT CTT CA-3' }\end{array}$ & & \\
\hline $\begin{array}{l}\text { Reverse } 5^{\prime} \text {-ATC CCC ATG GCA } \\
\text { AAC TCT TG-3' }\end{array}$ & \multirow{4}{*}{348} & \multirow{4}{*}{55} \\
\hline Exon 21 & & \\
\hline $\begin{array}{l}\text { Forward 5'-GCT CAG AGC CTG } \\
\text { GCA TGA A-3' }\end{array}$ & & \\
\hline $\begin{array}{l}\text { Reverse } 5^{\prime} \text {-CAT CCT CCC CTG } \\
\text { CAT GTG T-3' }\end{array}$ & & \\
\hline HER2 & \multirow{3}{*}{187} & \multirow{3}{*}{67} \\
\hline Exon 19 & & \\
\hline $\begin{array}{l}\text { Forward 5'-GCC CAC GCT CTT } \\
\text { CTC ACT CA-3' }\end{array}$ & & \\
\hline $\begin{array}{l}\text { Reverse } 5^{\prime} \text {-ATG GGG TCC TTC } \\
\text { CTG TCC TC- } 3^{\prime}\end{array}$ & \multirow{4}{*}{342} & \multirow{4}{*}{67} \\
\hline Exon 20 & & \\
\hline $\begin{array}{l}\text { Forward 5'-GCC ATG GCT GTG } \\
\text { GTT TGT GAT GG-3' }\end{array}$ & & \\
\hline Reverse 5'-ATC CTA GCC CCT & & \\
\hline
\end{tabular}

EGFR indicates epidermal growth factor receptor. 
TABLE 2. Clinicopathologic Characteristics of the SH of the Lung

\begin{tabular}{|c|c|c|c|c|c|c|c|}
\hline Case & Age/Sex (y) & Smoking Habit & Symptoms & Site & Tumor Size $(\mathrm{cm})$ & Therapy & Follow-up (mo) \\
\hline 1 & $45 / F$ & No & Incidental & RLL & 2.5 & $\mathrm{~L}$ & AW (33) \\
\hline 2 & $42 / \mathrm{F}$ & No & Cough & RLL & 3.5 & WR & AW (38) \\
\hline 3 & $50 / \mathrm{F}$ & No & Cough & LLL & 4 & WR & $\mathrm{AW}(50)^{*}$ \\
\hline 4 & $54 / \mathrm{M}$ & Yes & Cough & LLL & 2.5 & $\mathrm{~L}$ & AW (88) \\
\hline 5 & $35 / F$ & No & Incidental & RML & 3 & WR & AW (35) \\
\hline 6 & $58 / \mathrm{F}$ & No & Incidental & RLL & 3.5 & WR & AW (37) \\
\hline 7 & $59 / \mathrm{F}$ & Yes & Cough & LLL & 4. & $\mathrm{~L}$ & AW (102) \\
\hline 8 & $42 / \mathrm{F}$ & No & Incidental & RML & 1.5 & WR & AW (119) \\
\hline 9 & $25 / \mathrm{F}$ & No & Incidental & LLL & 3 & $\mathrm{~L}$ & AW (61) \\
\hline 10 & $44 / \mathrm{F}$ & No & Thoracic pain & RUL & 4 & WR & AW (37) \\
\hline 11 & $61 / \mathrm{F}$ & Yes & Incidental & RLL & 2.5 & $\mathrm{~L}$ & $\mathrm{AW}(51)$ \\
\hline
\end{tabular}

*Lymph node metastasis in a regional lymph node.

F indicates female; L, lobectomy; LLL, left lower lobe; M, male; RLL, right lower lobe; RML, right middle lobe; RUL, right upper lobe; WR, wedge resection.

The tumors had a mean size of $3.1 \mathrm{~cm}$ (range, 1.5 to $4.5 \mathrm{~cm}$ ) and predominantly affected the lower lobes of the lungs (8 cases).

At histologic examination, all cases showed the characteristic dual cell population, with a variable mixture of papillary, solid, hemorrhagic, and fibrotic patterns of growth. Three cases were predominantly papillary (Fig. 1A), 2 solid, 1 hemorrhagic, and 1 fibrotic.

Results of the immunohistochemical and FISH analyses are summarized in Table 3. Among markers with diagnostic value, TTF-1 was expressed in both components in all cases (Fig. 1B). Although all cases showed positive immunostain with EMA and cytokeratin in cuboidal cells, polygonal stromal cells were positive for EMA and cytokeratin in $10 / 11$ and $1 / 11$ cases, respectively. EGFR and HER2 expression as well as EGFR and $H E R 2$ gene copy number analysis by FISH were tested in 7 cases. All cases showed positive staining for EGFR in the surface cell component; polygonal cells immunoreacting in all but one (Fig. 1C). No immunostaining was recorded for HER2 in both components (Fig. 1D).

Basically, all cases showed a diploid (normal) signal for EGFR and HER2 (Fig. 1E) genes by FISH, whereas occasional cells (less than 3\%) displayed trisomy for EGFR in 2 cases (Fig. 1F).

Sequencing analysis did not show mutations in none of the analyzed exons of EGFR (exons 18-21), HER2 (exons 19 and 20), and $K-R A S$ (exon 2).

In $E G F R$ exon 20, a silent point mutation/variant at codon 787 (CAG to CAA, Q787Q) was found in 9 cases. This polymorphism was present in homozygous (6 cases) (Fig. 2) or in heterozygous (3 cases) status.

Microsatellites study was performed in 9 cases and results are summarized in Table 4. Overall, allelic losses were detected in 5 cases, whereas 4 did not show any microsatellite abnormality.

The most frequent altered microsatellite markers were those related to $p 16$ gene (D9S171 and D9S162). In fact, 4 cases showed LOH in these loci (3 at D9S162 and 1 at both D9S162 and D9S171).

Three cases were not informative at D9S171, whereas 1 at D9S162. Two cases showed allelic loss at the $R b$-related microsatellite markers ( 1 at D13S153 and 1 at D13S176). TP53 LOH was identified in only 1 case, whereas no $\mathrm{LOH}$ was disclosed in the microsatellite markers harboring FHIT gene (D3S1300 and D3S1312).

Two cases showed allelic loss on p16-related and $R b$-related markers, whereas no other combinations of LOH were detected. Microsatellite alterations evidenced by length variation were observed in 8 microsatellite loci of 3 cases and were widely distributed among the different microsatellites (2 each at D3S1300, D13S153, D13S176 and 1 each at D9S171 and TP53).

Of note, in all cases (8) in which it was possible to perform a separate microdissection of cuboidal surface and polygonal stromal cells, an identical $\mathrm{LOH}$ pattern was found in the 2 components (Fig. 3).

\section{DISCUSSION}

$\mathrm{SH}$ is a relatively uncommon benign lung tumor characterized by 2 cellular components consisting of surface cuboidal cells and of the diagnostic stromal polygonal cells arranged in several patterns (papillary, hemorrhagic, solid, sclerotic), usually combined one each other. ${ }^{33}$ Recently, the tumor was found to exhibit hypermetabolism on positron emission tomography scan. ${ }^{21}$ Electron microscopy features and immunoexpression for epithelial and pulmonary markers both in the cuboidal $(\mathrm{TTF}-1+$, EMA +, cytokeratins + , surfactant protein + ) and polygonal (TTF-1 +, EMA +, cytokeratins $-/+$, surfactant protein - ) cells strongly support that $\mathrm{SH}$ derives from a primitive respiratory epithelium. $6,10,14,27,33,34,37,39,41$ According to Chan and Chan, ${ }^{6}$ it seems conceivable that polygonal cells derive from a primitive respiratory epithelium lacking a complete differentiation but possibly able to achieve type II pneumocytes or Clara cells differentiation as instead showed by the surface cuboidal component.

However, the complete respiratory epithelium differentiation of the cuboidal cell component has lead some authors to doubt about their true neoplastic nature. $^{10,14,27,34}$ In particular, Illei et a $1^{14}$ suggest that surface lining cells of SH may partly represent entrapped alveolar 

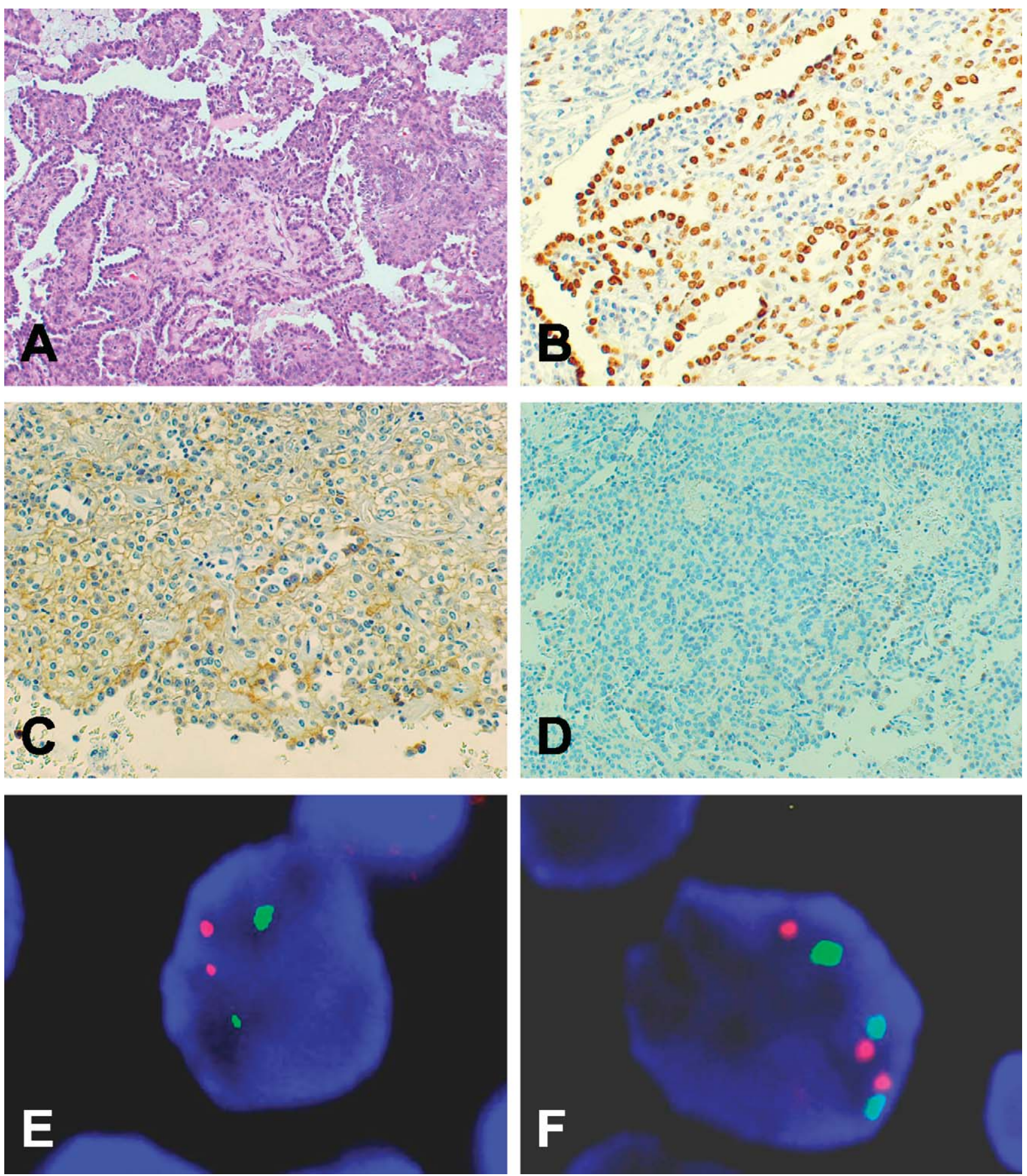

FIGURE 1. An example of papillary type SH (A) showing TTF-1 positivity (B) both in cuboidal surface and stromal polygonal cells. The tumor showed moderate immunostaining for EGFR (C), but no reaction for HER2 (D). SH displaying diploid signal (E) and trisomy (F) for EGFR set-up.

structures and not true neoplastic elements. Again, Wang et $\mathrm{al}^{34}$ state that the surface cuboidal cells and polygonal stromal cells in $\mathrm{SH}$ do not have a common origin based on immunohistochemical and ultrastructural analysis, showing an incomplete epithelial differentiation and some neuroendocrine features only in the latter.

Although it is likely that some of the glandular formations and/or small papillary projections lined by the 
TABLE 3. Results of the Immunohistochemical and FISH Analysis of the SH of the Lung

\begin{tabular}{|c|c|c|c|c|c|c|c|}
\hline \multirow[b]{2}{*}{ Case } & \multicolumn{5}{|c|}{ Immunohistochemistry (Cuboidal Surface Cells/Polygonal Stromal Cells) } & \multicolumn{2}{|c|}{ FISH } \\
\hline & CK & TTF-1 & EMA & EGFR & HER2 & EGFR & HER2 \\
\hline 1 & $+/-$ & $+/+$ & $+/+$ & $+/+$ & $-1-$ & - & - \\
\hline 2 & $+1+$ & $+/+$ & $+/+$ & $+/+$ & $-1-$ & —* & - \\
\hline 4 & $+1-$ & $+1+$ & $+/+$ & $+1-$ & $-1-$ & - & - \\
\hline 5 & $+1-$ & $+1+$ & $+1+$ & $+1+$ & $-1-$ & - & - \\
\hline 6 & $+1-$ & $+1+$ & $+1+$ & $+1+$ & $-1-$ & - & - \\
\hline 10 & $+1-$ & $+1+$ & $+1-$ & NA & NA & NA & NA \\
\hline 11 & $+1-$ & $+1+$ & $+1+$ & $+1+$ & $-1-$ & - & - \\
\hline
\end{tabular}

*Presence of occasional cells (less than $3 \%$ ) with EGFR trisomy.

CK indicates cytokeratins; EMA, epithelial membrane antigen; EGFR, epidermal growth factor receptor; NA, not available; TTF-1, thyroid transcription factor-1; + , positive; - , negative.

cuboidal cells, especially at the tumor periphery, may be entrapped alveoli, there are at least 2 convincing reasons, supporting the true neoplastic origin of both cell types.

First, some of the previously reported cases of SH with lymph nodes metastasis show both papillary formations covered by cuboidal surface cells and also solid sheets of polygonal stromal cells into the metastatic deposits. $^{20}$

Secondly, at molecular level Niho et al ${ }^{22}$ elegantly demonstrated that both cell types are monoclonal, showing the same methylation patterns by means of $\mathrm{X}$ chromosome-linked polymorphic markers (HUMARA and $P G K$ genes) analysis. These observations are further supported here by the finding of identical allelic loss pattern in several microsatellite loci in both components.

However, the molecular mechanisms underlying $\mathrm{SH}$ are largely unknown and etiopathogenesis remains a jigsaw puzzle. Only a few papers have analyzed the molecular features of this intriguing tumor. In particular, a recent study by Dacic et $\mathrm{al}^{9}$ showed that $\mathrm{SH}$ ( 9 cases)
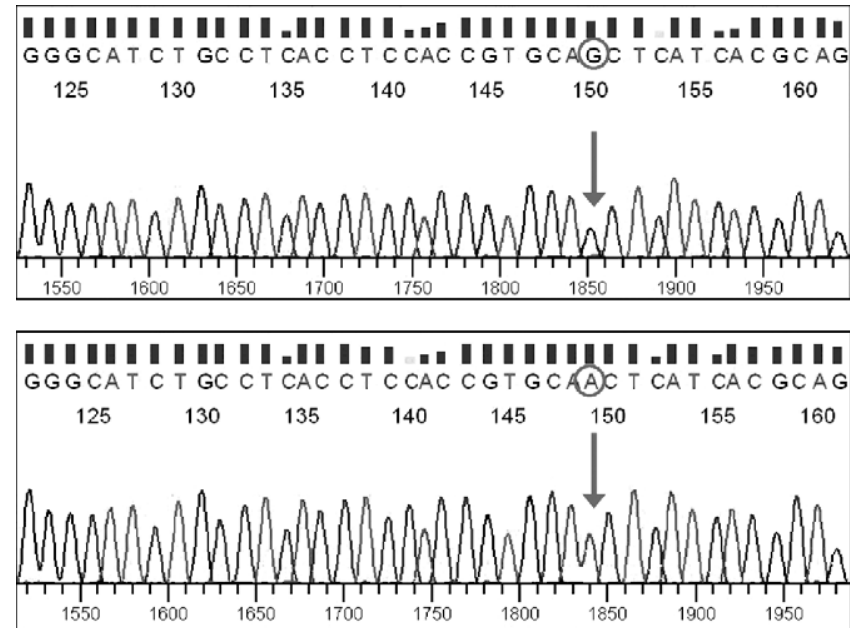

FIGURE 2. Part of the electropherogram of the exon 20 EGFR showing a normal sequence (at the top) and a CAG to CAA homozygous polymorphism at codon 787 (at the bottom). and BAC (10 nonmucinous and 4 mucinous) share several pattern of allelic loss for microsatellite markers located on chromosomal regions harboring important suppressor genes (ie, $M Y C L-1, M C C / A P C, p 16, \quad P T E N, p 53)$ involved in lung adenocarcinoma occurrence. Qualitative and quantitative alterations of microsatellite alterations differed only in a significant higher presence in $\mathrm{SH}$ of $\mathrm{LOH}$ on $5 \mathrm{q}$ (D5S.615), harboring the $A P C / M C C$ tumor suppressor gene. ${ }^{9}$ The authors then suggested that this latter finding could represent an early event in $\mathrm{SH}$ tumorigenesis as previously observed in premalignant lung lesions and/or pulmonary parenchyma adjacent to lung carcinomas.

By means of a different panel of microsatellite markers detecting specific chromosome regions comprising tumor suppressor genes (FHIT, Rb, p16, $p 53)^{1,2,8,12,28,35,36}$ deeply involved in lung cancer and adenocarcinoma histotype in particular. Overall, we found $\mathrm{LOH}$ in $55.5 \%$ of the analyzed cases then supporting the previous observations by Dacic et $\mathrm{al}^{9}$ concerning the finding of allelic losses in SH. However, we identified a lower rate of allelic losses if compared with the above-mentioned work in which only 1 out of $9 \mathrm{SH}$ did not show LOH for the tested markers. In our study, 4 cases did not show any allelic loss. Even if we consider the fractional allelic loss rate, the fractional allelic loss rate reported by Dacic et $\mathrm{al}^{9}(0.41)$ was higher than that observed here (0.10). Nevertheless, these apparent discrepancies may be related to the different panel of microsatellite markers adopted in these works.

The finding of $\mathrm{LOH}$ mainly restricted to $p 16$ and $R b$ gene-related markers in our study merits a brief comment. Wistuba et $\mathrm{al}^{35}$ and Aoyagi et $\mathrm{al}^{1}$ previously demonstrated that allelic loss of $p 16$ and $R b$ markers (together with losses at $5 \mathrm{q} / A P C$ and $11 \mathrm{q} /$ Int-2) represent frequent and early events in the pathogenesis of lung adenocarcinoma, particularly in bronchioloalveolar type, whereas allelic losses at $3 \mathrm{p}$ (FHIT region), at $8 \mathrm{p}$ ( $M Y C$ region), or $17 \mathrm{p}$ (p53 region) are relatively late findings commonly associated with malignant progression to invasive adenocarcinoma. ${ }^{1,8,12,28,35}$ 
TABLE 4. Microsatellite Analysis of the SH of the Lung

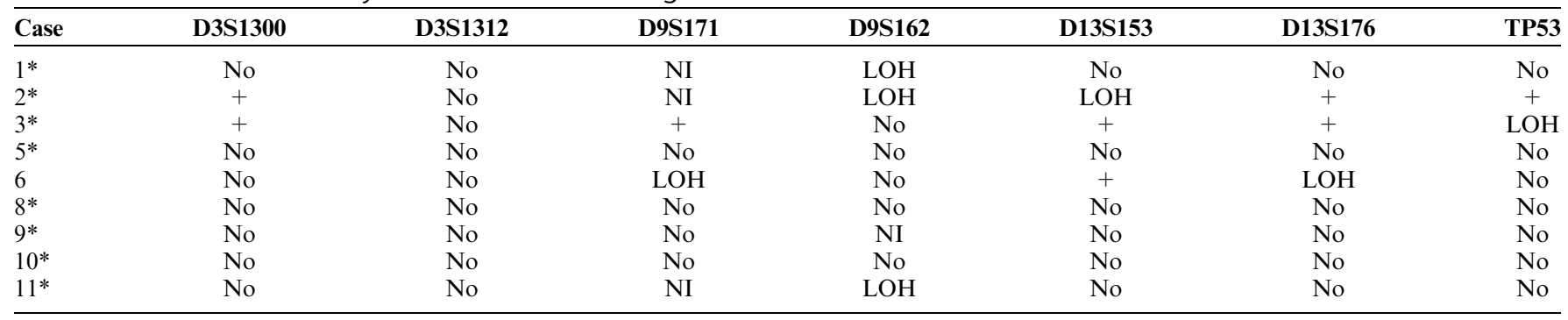

*Cases in which it was possible to analyze distinctly the surface cuboidal cells and the stromal polygonal cells.

NI indicates not informative; + , microsatellite alterations.

In addition, $\mathrm{LOH}$ at $9 \mathrm{p}$ region ( $p 16$ gene) along with loss at $13 \mathrm{q}$ ( $R b$ gene) is the most frequent allelic loss found in atypical adenomatous hyperplasia and in $\mathrm{nm}$ $\mathrm{BAC}$ in general. ${ }^{36}$

According to these observations, it seems conceivable that losses at $p 16$ and $R b$ genes could be implicated also in tumorigenesis of $\mathrm{SH}$, then supporting somewhat
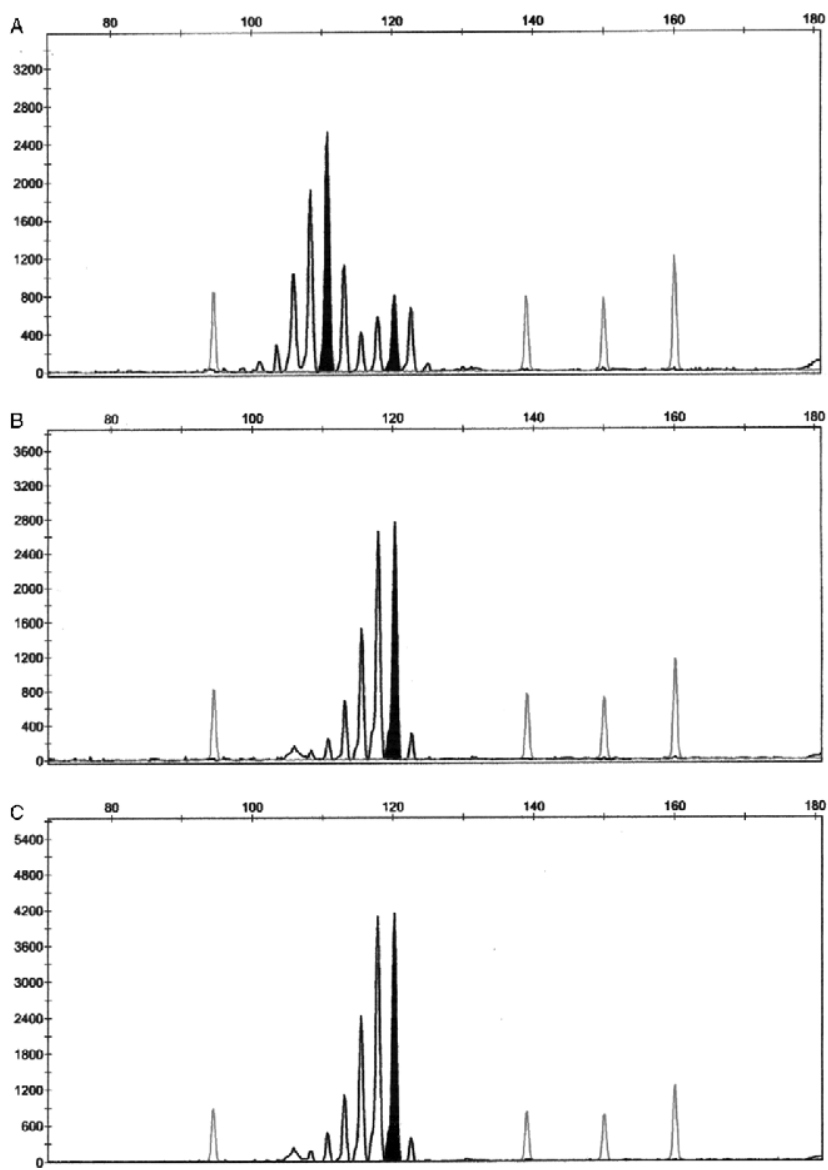

FIGURE 3. Electropherogram showing an example of $\mathrm{LOH}$ at TP53 locus ( $p 16$ locus) both in cuboidal surface (in the middle) and stromal polygonal (at the bottom) cells and the normal setup of the lymphoid tissue obtained from the same case (case no. 3) (at top). the idea of a relationship in the molecular mechanisms underlying BAC and $\mathrm{SH}$.

However, allelic losses involving chromosomal regions though to comprise tumor suppressor genes encoding for key cell cycle regulatory proteins, such as $\mathrm{p} 16, \mathrm{Rb}$, or $\mathrm{p} 53$, may be relatively nonspecific and is commonly found in several different neoplastic conditions. ${ }^{26}$ So, the allelic loss analysis in SH here seems more informative in confirming the clonal origin of both tumor components rather than to define peculiar molecular features at allelic loss analysis.

It is also interesting to note that nm-BAC and $\mathrm{SH}$ share several clinical characteristics mostly affecting middle-aged, nonsmoking women of Asian origin. ${ }^{19,29,33}$

Several works have found a high rate of somatic mutations of EGFR (up to 59\%) in lung adenocarcinoma with prominent BAC features or pure nm-BAC, particularly when occurring in people from East Asia. ${ }^{3,4,7,11,13,17-19,23-25,29-31,40}$ In addition, EGFR mutations in lung adenocarcinoma are significantly correlated with female sex, nonsmoker status, BAC-like histotype, and Asian ethnicity. ${ }^{17,19,23-25,29,40}$ All the above features are important prerequisite to achieve dramatic clinical response to EGFR tyrosine kinase inhibitors (gefitinib and erlotinib). ${ }^{17,19,23-25,29}$ Of note, similar clinicopathologic characteristics are also associated with somatic mutations of $H E R 2$ in a smaller subset of patients, ${ }^{4,30}$ whereas mutations of HER2 and EGFR are mutually exclusive to each other and also with $K-R A S,{ }^{4,13}$ another gene frequently mutated in lung adenocarcinoma but usually associated with smoking patients and also with a negative predictive value using EGFR tyrosine kinase inhibitors. ${ }^{25}$ Although all SH showed positive staining for EGFR at immunohistochemistry, no gene gains were detected at FISH analysis, all 7 tested cases resulting diploid, 2 of which with only occasional trisomic cells. Most important, all 11 cases of SH appeared "wild-type" at sequencing analysis of EGFR, HER2, and $K-R A S$ genes.

Although it is widely accepted that EGFR expression by immunohistochemistry may be considered a rough way to detect $E G F R$ abnormalities, the absence of $E G F R$ alterations by FISH or sequencing analysis does not support a role of $E G F R$ as molecular promoter of $\mathrm{SH}$ 
tumorigenesis. Lack of FISH alterations and mutational events on HER2 a wild-type set-up of $K$-RAS seems to convincingly rule out a possible role of all these genes in $\mathrm{SH}$ tumorigenesis as instead happen in the molecular pathway of adenocarcinoma in general and BAC in particular. ${ }^{18,19,25,29}$ Marginally, the presence of polymorphisms at EGFR exon 20 in all cases of SH confirm the high prevalence of this variant at codon 787 in white and Italian people. ${ }^{15}$

In conclusion, we have demonstrated here that $\mathrm{SH}$ harbors frequent microsatellite alterations at p16 and $R b$-related akin to those commonly found in early-stage adenocarcinoma and nm-BAC, but also relatively nonspecific given that these cell cycle regulatory genes are involved in many other neoplasms. Most interestingly, these allelic losses were concordant in surface cuboidal and stromal polygonal elements, then suggesting the clonality and neoplastic nature of both SH components. However, apart from the immunohistochemical expression of EGFR in $\mathrm{SH}$, the normal EGFR and HER2 gene copy number at FISH and the lack of EGFR, HER2 and $K-R A S$ mutations at direct sequencing study seems to suggest that $\mathrm{SH}$ and $\mathrm{BAC}$ have a different molecular tumorigenesis.

\section{REFERENCES}

1. Aoyagi Y, Yokose T, Minami Y, et al. Accumulation of losses of heterozygosity and multistep carcinogenesis in pulmonary adenocarcinoma. Cancer Res. 2001;61:7950-7954.

2. Awaya H, Takeshima Y, Amatya VJ, et al. Inactivation of the p16 gene by hypermethylation and loss of heterozygosity in adenocarcinoma of the lung. Pathol Int. 2004;54:486-489.

3. Blons $\mathrm{H}$, Cote JF, Le Corre D, et al. EGFR mutations in lung cancer are linked to bronchioloalveolar differentiation. Am J Surg Pathol. 2006;30:1309-1315.

4. Buttitta F, Barassi F, Fresu G, et al. Mutational analysis of the HER2 gene in lung tumors from Caucasian patients: mutations are mainly present in adenocarcinomas with bronchioloalveolar features. Int J Cancer. 2006;119:2586-2591.

5. Cavazza A, De Marco L, Pellegrino S, et al. Sclerosing hemangioma with a predominant sclerotic pattern: a rare pulmonary lesion which can be misdiagnosed. Adv Clin Pathol. 2002;6:131-134.

6. Chan ACL, Chan JKC. Pulmonary sclerosing hemangioma consistently expresses thyroid transcription factor-1 (TTF-1): a new clue to its histogenesis. Am J Surg Pathol. 2000;24:1531-1536.

7. Chan SK, Gullick WJ, Hill ME. Mutations of the epidermal growth factor receptor in non-small cell lung cancer - search and destroy. Eur J Cancer. 2006;42:17-23.

8. Dacic S, Sasatomi E, Swalsky PA, et al. Loss of heterozygosity patterns of sclerosing hemangioma of the lung and bronchioloalveolar carcinoma indicate a similar molecular pathogenesis. Arch Pathol Lab Med. 2004;128:880-884.

9. Dacic S, Finkelstein SD, Yousem SA. Clonal selection of adenocarcinoma of the lung as determined by loss of heterozygosity. Exp Mol Pathol. 2005;78:135-139.

10. Devouassoux-Shisheboran M, Hayashi T, Linnoila RI, et al. A clinicopathologic study of 100 cases of pulmonary sclerosing hemangioma with immunohistochemical studies. TTF-TT1 is expressed in both round and surface cells, suggesting an origin from primitive respiratory epithelium. Am J Surg Pathol. 2000;24: 906-916.

11. Eberhard DA, Johnson BE, Amler LC, et al. Mutations in the EGFR and in KRAS are predictive and prognostic indicators in patients with NSCLC treated with chemotherapy alone or in combination with erlotinib. J Clin Oncol. 2005;23:5900-5909.
12. Girard L, Zochbauer-Muller S, Virmani AK, et al. Genome-wide allelotyping of lung cancer identifies new regions of allelic loss, differences between small cell lung cancer and non-small cell lung cancer, and loci clustering. Cancer Res. 2000;60: 4894-4906.

13. Han SW, Kim TY, Jeon YK, et al. Optimization of patient selection for gefitinib in non-small-cell lung cancer by combined analysis of epidermal growth factor receptor mutation, K-ras mutation, and Akt phosphorylation. Clin Cancer Res. 2006; 12:2538-2544.

14. Illei PB, Rosai J, Klimstra DS. Expression of thyroid transcription factor-1 and other markers in sclerosing hemangioma of the lung. Arch Pathol Lab Med. 2001;125:1335-1339.

15. Leone F, Cavalloni G, Pignochino Y, et al. Somatic mutations of epidermal growth factor receptor in bile duct and gallbladder carcinoma. Clin Cancer Res. 2006;12:1680-1685.

16. Liebow AA, Hubbell DS. Sclerosing hemangioma (histiocytoma, xanthoma) of the lung. Cancer. 1956;9:53-75.

17. Lynch TJ, Bell DW, Sordella R, et al. Activating mutations in epidermal growth factor receptor underlying responsiveness of nonsmall-cell lung cancer to gefitinib. $N$ Engl $J$ Med. 2004;350: 2129-2139.

18. Marchetti A, Martella C, Felicioni L, et al. EGFR mutations in nonsmall-cell lung cancer: analysis of a large series of cases and development of a rapid and sensitive method for diagnostic screening with potential implications on pharmacologic treatment. $J$ Clin Oncol. 2005;23:857-865.

19. Miller VA, Kris MG, Shah N, et al. Bronchioloalveolar pathologic subtype and smoking history predict sensitivity to gefitinib in advanced non-small cell lung cancer. J Clin Oncol. 2004;22: 1103-1109.

20. Miyagawa-Hayashino A, Tazelaar HD, Langel DJ, Colby TV Pulmonary sclerosing hemangioma with lymph node metastases: report of 4 cases. Arch Pathol Lab Med. 2003;127:321-325.

21. Neuman J, Rosioreanu A, Schuss A, et al. Radiology-pathology conference: sclerosing hemangioma of the lung. Clin Imaging. 2006;30:409-412.

22. Niho S, Suzuki K, Yokose T, et al. Monoclonality of both pale cells and cuboidal cells of sclerosing hemangioma of the lung. $\mathrm{Am}$ J Pathol. 1998;152:1065-1069.

23. Paez JG, Janne PA, Lee JC, et al. EGFR mutations in lung cancer: correlation with clinical response to gefitinib therapy. Science. 2004;304:1497-1500

24. Pao W, Miller V, Zakowski M, et al. EGFR gene mutations are common in lung cancer from "never smokers" and are associated with sensitivity of tumors with gefitinib and erlotinib. Proc Natl Acad Sci. 2004;101:13306-13311.

25. Pao W, Wang TY, Riely GJ, et al. KRAS mutations and primary resistance of lung adenocarcinomas to gefitinib or erlotinib. PLoS Med. 2005;2:e17.

26. Raptis S, Bapat B. Genetic instability in human tumors. EXS. 2006; 96:303-320.

27. Rodriguez-Soto J, Colby T, Rouse R. A critical examination of the immunophenotype of pulmonary sclerosing hemangioma. $\mathrm{Am}$ J Surg Pathol. 2000;24:442-450.

28. Sanz-Ortega J, Saez MC, Sierra E, et al. 3p21, 5q21 and 9p21 allelic deletions are frequently found in normal bronchial cells adjacent to non-small-cell lung cancer, while they are unusual in patients with no evidence of malignancy. J Pathol. 2001;195: 429-434.

29. Shigematsu H, Lin L, Takahashi T, et al. Clinical and biological features associated with EGFR gene mutations in lung cancers. J Natl Cancer Inst. 2005;97:339-346.

30. Stephens P, Hunter C, Bignell G, et al. Lung cancer: intragenic ERBB2 kinase mutations in tumours. Nature. 2004;431:525-526.

31. Tam IY, Chung LP, Suen WS, et al. Distinct epidermal growth factor receptor and KRAS mutation patterns in non-small-cell lung cancer patients with different tobacco exposure and clinicopathologic features. Clin Cancer Res. 2006;12:1647-1653.

32. Tanaka I, Inoue M, Matsui Y, et al. A case of pneumocytoma (so-called sclerosing hemangioma) with lymph node metastasis. Jpn J Clin Oncol. 1986;16:77-86. 
33. Travis WD, Brambilla E, Muller-Hermelink HK, et al, eds. Tumours of the Lung, Pleura, Thymus and Heart. Pathology \& Genetics. World Health Organization Classification of Tumours. Lyon: IARC Press; 2004.

34. Wang E, Lin D, Wang $\mathrm{Y}$, et al. Immunohistochemical and ultrastructural markers suggest different origins for cuboidal and polygonal cells in pulmonary sclerosing hemangioma. Hum Pathol. 2004;35:503-508

35. Wistuba II, Behrens C, Virmani AK, et al. High resolution chromosome $3 p$ allelotyping of human lung cancer and preneoplastic/preinvasive bronchial epithelium reveals multiple, discontinuous sites of $3 \mathrm{p}$ allele loss and three regions of frequent breakpoints. Cancer Res. 2000;60:1949-1960.

36. Yamasaki M, Takeshima Y, Fujii S, et al. Correlation between genetic alterations and histopathological subtypes in bronchioloalveolar carcinoma and atypical adenomatous hyperplasia of the lung. Pathol Int. 2000;50:778-785.
37. Yamazaki K. Type-II pneumocyte differentiation in pulmonary sclerosing hemangioma: ultrastructural differentiation and immunohistochemical distribution of lineage-specific transcription factors (TTF-1, HNF-3 alpha, and HNF-3 beta) and surfactant proteins. Virchows Arch. 2004:445:45-53.

38. Yano M, Yamakawa Y, Kiriyama M, et al. Sclerosing hemangioma with metastases to multiple nodal stations. Ann Thorac Surg. 2002;73:981-983.

39. Yoo SH, Jung KC, Kim JH, et al. Expression patterns of markers for type II pneumocytes in pulmonary sclerosing hemangiomas and fetal lung tissues. Arch Pathol Lab Med. 2005;129:915-919.

40. Yoshida Y, Shibata T, Kokubu A, et al. Mutations of the epidermal growth factor receptor gene in atypical adenomatous hyperplasia and bronchioloalveolar carcinoma of the lung. Lung Cancer. 2005;50:1-8.

41. Yousem SA, Wick MR, Singh G, et al. So-called sclerosing hemangioma of lung. An immunohistochemical study supporting a respiratory epithelial origin. Am J Surg Pathol. 1988;12:582-590. 